\title{
No one, everyone, anyone
}

\author{
Nathan Harter \\ Professor, Department of Leadership and American Studies, Christopher Newport University, \\ Newport News, VA, USA
}

Prospective leaders are frequently advised to know themselves. Such knowledge takes the form of an image, requiring the use of the imagination to create an identity based on some kind of selfconcept. This process of looking inward is incomplete without also gaining critical distance from the self. Three prominent philosophers had offered heuristics to imagine oneself as somebody else. Plato asked, for example: what if you were no one - literally anonymous? How would that alter your perspective? Immanuel Kant suggested that you consider yourself and your situation from everyone's point of view and not just your own. And John Rawls asked, in regards to constituting a group or organization or even something so simple as a contract: what if you might be anyone, especially the least advantaged? Would the arrangement you presently favor seem fair to anyone? By adopting these heuristics and getting outside of one's self, a leader might avoid typical ethical failings and actually gain a more authentic self-concept.

Keywords: leader, self, self-concept, identity, philosophy, image

\section{KNOW THYSELF}

John Gardner (1990 [1993], p. 170) memorably stated: 'Somewhere, somehow, with all the courses, the extracurricular activities, the lessons learned from contemporaries, the help from wise elders - the young person [who aspires to leadership] must gain the necessary knowledge of self.' A number of writers concur (for example, Kouzes and Posner 1987, p. 298; Bennis 1989, ch. 3; Ciulla 2004, p. 324; London and Maurer 2004, pp. 230-235; Roberts 2008). It has become a commonplace in the literature, largely because it contains wisdom going back to Greek antiquity (see Foucault 2001 [2005]; Harter 2016).

How then does a prospective leader acquire knowledge of the self? Many methods present themselves, ranging from quiet introspection to assessments such as the Myers-Briggs Type Indicator (MBTI), all toward the goal of making an object of one's self. The project seems to call for turning the light of attention inward and bringing it all to the surface - as though the self were simply there, lying in the depths, waiting to be uncovered. If you get stuck, you could launch a $360^{\circ}$ evaluation (Sherman 1995) or conduct 'systematic reflexivity' (see Bourdieu and Wacquant 1992). The assumption in each case is the same, namely that there is a self to uncover, something personal and interior.

It may be asking too much, however, to behold the self at a glance, naked and whole. Self concept will have to be mediated.

\section{THE SELF AS IMAGE}

Whatever it turns out to be, the 'self' is elusive quarry. It changes over time, it hides, it is mired in contradictions, it mirrors the milieu whence it came, it presents 
itself in symbolic languages not easily reducible to simple propositions. In the best of circumstances, one acquires but an image of the self. And though with time and study one might continue to add to that image or revise it, the image is still - and always will be - a veil draped over a complex reality, matching its contours loosely.

The Spaniard José Ortega y Gasset explicitly adopted this epistemological metaphor of a drapery in the early pages of his Meditations on Quixote (1914 [1961]). He called the image a superficial tapestry, the surface as opposed to the depths, and a screen 'behind which the rest of it lies hidden and aloof' (ibid., p. 60). Citing David Hume (1739 [1975]), Shaun Gallagher (2000, p. 19) made a similar claim from the cognitive sciences that 'the self consists of a bundle of momentary impressions that are strung together by the imagination.' In this vein, he argued, we might refer to a narrative self, which is a dynamic version of the belief one has about identity. Other attempts to capture the idea of the self as an image or as a collection of images include archetypal psychology (for example, Sells 2000), mythology (for example, Eliade 1991), and perhaps surprisingly economics (Boulding 1961). At least there are those among the social psychologists who contend that the place to look for those images of the self lies on the exterior, in the various ways that other people regard you (for example, Mead 1913).

Some leadership theorists have gone so far as to decide that there is nothing but the image (for example, Mazlish 1990). If indeed the image is all we can ever really know, it would be unnecessary and misleading, they say, to assume there is anything substantive behind the imagery. Maybe we construct this image of a self and then reify our construction by calling it something as though it existed independent of our exertions. The self is indeed an image, they would argue, and nothing more.

Because self-concept is based on some kind of image, no matter how complicated or strange, there is apparently a role for the imagination in excavating or inventing whatever it is that prospective leaders are supposed to 'know' about themselves. The imagination seems to be required.

\section{GAINING DISTANCE}

Despite admonitions to 'know thyself,' be authentic, and become aware of one's core values, leadership can also be said to require a capacity to imagine oneself differently to see oneself from other points of view and not be trapped by any single image, no matter how intimate. Rather, one must also gain some critical distance from what is inward and adopt a different vantage point, outside of the self. It is a paradox that self-concept might be served by getting outside of one's self.

This paper introduces three different ways of imagining, ways that are based on passages from the work of three eminent philosophers who in one form or another have made considerable contributions to thinking about issues surrounding leadership. These philosophers are Plato, Immanuel Kant, and John Rawls. We shall hear (a) Plato urge his interlocutor to consider himself as though he were no one; (b) Kant recommend that the prospective leader try to adopt the perspective of everyone; and (c) Rawls explain what he meant that one should be ready to look upon decisions as anyone. In other words, they advise prospective leaders to move away from scrutinizing the self as it lies within and instead move outward, toward getting outside the self and accepting an impersonal pronoun. 


\section{BEING NO ONE: PLATO'S 'RING OF GYGES'1}

In Plato's dialogue known as the Republic (1968, Book II, 359d-360b), one of Socrates's interlocutors recounts the fable of an ancestor of Gyges, about a lowly shepherd who discovers a ring that enables him to disappear at will. Glaucon claims that by exploiting this magic ring, the shepherd was able to displace the king, seduce the queen, and position himself to flourish. Glaucon challenges Socrates: 'And who in the same situation would not do likewise?' Glaucon supposes that under the same conditions even the most virtuous person would follow his or her desires. Of course, what Glaucon describes in telling the story is a fiction, a dream-like fantasy that never existed in reality (Voegelin 1957, p. 76). Because it is a fantasy, its connection to reality makes the exercise of limited use. If we did in fact live in a dream-state of endless gratification and self-indulgence, where there are no consequences for any of our actions, then of course we would do as we like. In effect, Glaucon is saying that if we are nothing but appetitive creatures, then it stands to reason that we would strive to satisfy our desires. But that is not the world we live in. That is not who we are as human beings. Glaucon himself admits later in this dialogue that such a world would be more of a pig sty than a city of human beings (Book II, 372d).

Nevertheless, there is something useful to be learned in using the imagination to construct such a self-gratifying scenario, not least the realization that such a world does not exist. This question of the unaccountable shepherd permits Socrates to explore the nature of virtue that persists whether you are detected by others or not; so he asks Glaucon, is your virtue really dependent exclusively on the fear of detection? Should it matter whether you can actually get away with it? Through a series of questions, Socrates reveals the extent to which Glaucon's account of virtue is impoverished. Such an account of what it means to be human is equally impoverished.

And yet, as A.E. Taylor once pointed out, Glaucon raises a legitimate worry. It happens often enough that people behave differently once they realize they are being observed (1926 [2001], pp. 270f; see for example Roethlisberger and Dickson 1934, on the Hawthorne Effect). We can understand at an intuitive level the temptation to exploit such a power to disappear or at least to elude detection.

Not only this, but behind Glaucon's imagining of magic powers is the genuine predicament of leaders who seem to be one thing when in fact they are something else; they hide their authentic selves from the scrutiny of others (Bloom 1968, p. 341). Their rhetoric and sophistry serve as a cloak 'enchanting' the citizen and enabling them to gratify their desires undetected and therefore unsuspected. Lysias, for instance, is reported to have accused the Thirty Tyrants of using cries of justice as a pretext for self-dealing (Nussbaum 1998, p. 13). Their rhetoric - like the magic ring in Glaucon's fantasy is said to render their character invisible to followers.

Imagining oneself as anonymous, as no one in particular, serves as a heuristic device. By removing the scrutiny and judgment of others, when nobody else is looking (or when nobody has the courage to hold you to account ${ }^{2}$ ), would you change your behavior? It is a fair question for leaders to ask themselves. In this fashion, Plato raised at least two concerns that would later be addressed in the literature on leadership.

First, for authentic leadership, outward speech and behavior are meant to be congruent with one's inward character (Gardner et al. 2011). To what extent can leaders be

1. There is some dispute about whether it is the ring of Gyges or of an ancestor of Gyges (see Laird 2001).

2. See Chaleff 2009; Harter 2016. 
false somehow, hypocrites? It certainly happens. Niccolò Machiavelli (1532 [1991]) even recommended it, as the occasion requires. But if a leader desires to lead authentically, he or she must have self-knowledge. Otherwise, how would he or she achieve congruence? Plato's fable suggests that self-knowledge might be improved by imagining oneself as no one, literally anonymous, evading detection. Even then, one must not evade the scrutiny from one's own self.

Second, leaders often stumble ethically because power spreads a gauze of justification over what leaders do, as though how one is perceived by others makes certain choices permissible that otherwise wouldn't be (see for example Price 2006). Self-concept based on imagining oneself as no one penetrates that gauze of justification. Ask yourself: could you do that if you weren't the leader, if you were (in effect) a nobody? If you could not, the next question is as follows: how is it justified simply because you are the leader?

The exercise injects a tone of humility. Not to put too fine a point on it, maybe without the 'cloak' of leadership, you really are nobody. What does that say about you?

\section{BEING EVERYONE: KANT'S IDEA OF JUDGMENT}

Centuries after Plato, in a different milieu, Immanuel Kant struggled to explain how judgment as a faculty of the mind works. Kant was interested in several types of judgment, such as moral judgment, aesthetic judgment, and practical judgment. In each case, he urged the one making a judgment to incorporate other points of view - in fact, as many points of view as possible - and not trust one's own limited perspective.

In her study of Kantian judgment, Hannah Arendt wrote (1971 [1978], p. 38): 'Nothing that appears manifests itself to a single viewer capable of perceiving it under all its inherent aspects. The world appears in the mode of it-seems-to-me, depending on particular perspectives ...' Accordingly, she wrote (ibid., p. 21), 'every appearance, its identity notwithstanding, is perceived by a plurality of spectators.' Or as the Czech philosopher Jan Patočka (1995 [1998], p. 92) was to put it: 'A thing is inexhaustible in its aspects.' To understand anything is in part to adopt and integrate multiple points of view.

In ethics, for example, Kant taught a principle of reciprocity, in which you are to imagine yourself as the other person in a transaction and try to understand how he or she might feel (Kant 1785 [1997], §2:429; Kant 1797 [1991], p. 265). Taking this further, he taught a principle of universalizability, in which you are to imagine everyone else in the exact same situation, confronted with the exact same predicament, and try to understand how you would want them to decide (Kant 1785 [1997], §1:402-403; see also $\S 2: 421$ and 431). Kant had written that conscience depends on thinking of someone else as the judge of your actions (1797 [1991], p. 234).

In his lectures on anthropology, Kant had differentiated between a private sense and a communal sense, the latter of which serves as a corrective for the former (Arendt 1971 [1978], p. 50; Fleischacker 2013, p. 17). You can temporarily suspend your identity and thereby subject yourself to correction. To do so, one must 'think in the position of everyone else.' Kant referred to this as being broad-minded (Fleischacker 2013, p. 22).

Obviously, by the same token you cannot simply accept what others tell you; there is still work for you to do in order to consider yourself 'enlightened,' for that responsibility is central to his argument. According to Hannah Arendt (1954 [1968]), you are 
not required to go around literally taking a poll of everyone in the room. Instead, you regard the one situation in which you find yourself from different modes, as though you were this person and that person and somebody else - not least somebody who is not present or cannot speak on their own behalf. From your imagination, you adopt multiple perspectives, including perspectives across time, such as wisdom from the past and an imagined retrospect from the future. Taken altogether, you will then possess a fuller understanding of the object you wish to judge. In Kant's (1790 [1914], part I, §38) own words, then, 'we are justified in presupposing universally in every man those subjective conditions of the Judgement which we find in ourselves ...' What is of interest therefore would be:

a faculty of judgement, which in its reflection takes account (a priori) of the mode of representation of all other men in thought; in order as it were to compare its judgement with the collective Reason of humanity, and thus to escape the illusion arising from the private conditions that could be so easily taken for objective, which would injuriously affect the judgement. This is done by comparing our judgement with the possible rather than the actual judgements of others, and by putting ourselves in the place of any other man, by abstracting from the limitations which contingently attach to our own judgement. (Kant 1790 [1914], part I, §40, emphasis in original)

The goal is to imagine every conceivable point of view before rendering a verdict. This may necessitate actually consulting other people, including writings from the past, in order to inform the imagination for the purpose of transcending one's limited point of view. Ultimately, a successful leader should be literally circumspect, seeing the situation from every possible angle.

It doesn't stop there, of course. What can one do with a multiplicity of perspectives? Michel Foucault (2008, p. 89), in his Introduction to Kant's Anthropology, explained that for Kant 'multiplicity, as it is given to the senses, is not yet ordered ...' It is a hodge-podge, a mess, an array of possibilities until there is some kind of integrating order that makes a sense of it as a whole. Only then can a person exercise some sort of judgment. 'A judgment reached in advance of this ordering risks being false' (ibid.). We might say that a multiplicity passes out of existence once it becomes a unified whole. Only then should the leader judge what to do.

This process pertains to a leader's self-concept, as well. An individual human being is a multiplicity of powers and drives. A leader must come to order or integrate or unify somehow that multiplicity within, if he or she is to judge. The multiplicity must be constellated. But to do that, first the leader must gather or assemble the multiplicity to begin with. So also when judging what to do as a leader, the first task is to gather or assemble the multiplicity of opinions and perspectives into one's own attention.

In the literature on leadership, Ron Heifetz (1994) invited leaders to take what he calls a balcony view of a situation, from above, to see the waltz unfolding as a whole, and not limit yourself to the perspective of any of the dancers down on the floor. Kant had been encouraging a different move with regard to oneself, that is, gaining critical distance from a vantage point that incorporates the vantage points of others - as other dancers might see you. The difference is not trivial, inasmuch as Heifetz appears to describe a transcendent position or God's-eye-view that Kant would have considered beyond our capacity as human beings to achieve. ${ }^{3}$

3. The differences are explored in Nagel (1986 [1989]) and before him Sidgwick (1907 [1981]). 
A leader is advised therefore to assimilate as many points of view as possible mentors, peers, followers, beneficiaries, rivals, critics, historians, and other stakeholders - with an ideal of integrating all of them, so that one might judge rightly.

\section{BEING ANYONE: RAWLS'S 'VEIL OF IGNORANCE'}

From the twentieth century, John Rawls avoided describing in particular what ought to be done in any given situation; instead, he set forth a proposal about how people together might resolve what ought to be done in a manner that increased the likelihood of fairness and therefore assent. You are likelier to have done so if you were reliably impartial, totally ignorant of your particular stake in the outcome. Suppose you could be anyone. When you don't know which person you will be in a given institution, you will reasonably guard against the possibility that you might end up being a marginalized member, disadvantaged or disenfranchised. You will do this by creating an institution designed to ameliorate these conditions, without necessarily impeding the freedom of others. In game theory, they refer to the minimax principle as a way of responding to uncertainty: play the game so that you minimize your maximum losses (see for example Rapoport 1966 [1999]; Schellenberg 1982). ${ }^{4}$

In the landmark A Theory of Justice, John Rawls (1971) explained the heuristic which he names 'the veil of ignorance' as a way of overcoming 'the specific contingencies which put men at odds and tempt them to exploit social and natural circumstances to their own advantage' (ibid., p. 136). In an extensive critique, Amartya Sen $(2011$, p. 128) did conclude that this idea of a veil of ignorance 'is a very effective device for making people see beyond their personal vested interests and goals.' It offers a version of what Adam Smith (1759 [2010]) had earlier advised, of adopting the role of an impartial observer in order to gain some critical distance from one's own position (ibid., part III, ch. 1).

The veil of ignorance works like this. In order to negotiate an agreement among people, according to a procedure regarded by the parties as fair, Rawls recommended putting the participants into an 'original position' where they can design an acceptable arrangement for living together or doing business, very much like the social contract approaches to justice seen in Hobbes and Locke. The goal or objective would be to obtain consent, in advance, from all of the participants, even though (as he argues) that contract is likelier to be fair if the process that the parties use to create it was fair. This is why Rawls recommended the veil of ignorance: what this means is that during the negotiation the parties 'do not know how the various alternatives will affect their own particular case [so that] they are obliged to evaluate principles solely on the basis of general considerations' (Rawls 1971, p. 137). ${ }^{5}$

Behind the veil of ignorance, the parties do know certain things about the way the world works, but what they do not know is which person they would be once the contract becomes effective. In other words, no one knows his or her place in society, his or her fortune, capacities, liabilities, or even those values that would have been the

4. The minimax principle should be credited originally to John von Neumann (1928).

5. Although Rawls acknowledges getting the idea of the veil of ignorance in part from an economist who was trying to develop a utilitarian theory (Rawls 1971, p. 137, n. 11), the idea of removing oneself as a unique party and regarding the situation in the guise of a neutral third person also derives from Immanuel Kant, whose appeal to universability (as well as reversibility) means much the same thing, as we saw earlier (for example, Rawls 1971, pp.140f). 
product of one's upbringing, since nobody knows the circumstances under which he or she will have been raised (ibid., p. 137). 'No one knows his situation in society nor his natural assets, and therefore no one is in a position to tailor principles to his advantage' (ibid., p. 139). 'If a knowledge of particulars is allowed, then the outcome is biased by arbitrary contingencies' (ibid., p. 141). Therefore, all of that identifying information is erased, scrubbed completely, even before the parties undertake the project of designing their contract. These things are contingencies, after all, over which humans have little or no control, so there is no justification in basing outcomes on them. Can you take credit for your gender, race, age, or aptitudes? By going behind the veil of ignorance, you reduce the temptation to serve your own interests, since you don't know your interests. In addition, you reduce the appearance of impropriety, since in the original position nobody has reason to suspect anyone else of self-dealing. In short, you eradicate the contingencies without removing anyone's awareness of the role that contingencies will play once everyone steps out from behind the veil.

Rawls was aware that the veil of ignorance is only a heuristic and not some realworld possibility (ibid., p. 139). He did not expect flesh-and-blood human beings to gather on a hilltop to devise such a charter. His work is a thought experiment, an act of the imagination, in much the same way that Plato and Kant had recommended. Rawls did welcome extending the thought experiment to include some sort of grand referee who mediates among those behind the veil, partly to keep them from discovering each other's identity, but also to ensure that the other rules he recommended in his book are strictly followed. If these rules are followed, Rawls argued, then everyone will ultimately agree with one another in crafting a just arrangement (ibid., p. 139).

To put this another way, the leader has to drop his or her identification with the position of leader. The leader has to drop other, more intimate features of identity. The leader must go through the process of imagining what it would be like to be somebody else. Which of these participants is one of life's winners? Which of these is a loser? Would I want to be in the 'loser's' position? Probably not. What therefore can be done for the loser? How can this be made fair, for anyone found at a disadvantage?

The objective is that once you evaluate a given social order from the point of view of anyone who is going to participate in that order, you are likelier to recognize and perhaps remedy injustices that would otherwise not affect you. The evaluation becomes less about you and your interests and more about the overall fairness of the arrangement. By imagining yourself as the least advantaged participant (as for instance a racial minority or a woman or a child or a prisoner), your natural self-interest will from that vantage point alert you to what might be problematic. You use a natural self-regard during the creative process to endorse an arrangement that diminishes the impact of self-regard later.

It helps to stop for a moment and ask, what if I were anyone?

\section{CONCLUSION}

The purpose of this paper was not to suggest that prospective leaders disavow their own identity or pretend they aren't who they say they are. On the contrary. By using these three devices, which I have rendered as impersonal pronouns (No one, Everyone, and Anyone), a prospective leader can imagine being stripped of distracting features that often get leaders into trouble. Peter Singer (1979 [1999], p. 279) concurs: 'The ethical point of view does ... require us to go beyond a personal point of view to the standpoint of an impartial spectator.' 
It was Plato who had famously argued, in the Gorgias (1998), that human beings so often misjudge both themselves and each other because they are easily distracted by incidental features such as wealth and appearances and reputation. The underlying character that is 'truly you' has so many accretions that have little or nothing to do with excellence that your character can get overlooked, which is why Plato concluded that to judge rightly, one must have shed everything else, as in death. Likewise, one's judges must have shed them as well, so they are not likewise distracted. Plato refers to this encounter as the judgment of the dead (Gorgias, 523a4-b3), and the lesson is that by gaining some critical distance from oneself, you actually gain a clearer perspective on who you are - and on what kind of leader you promise to become. 


\section{REFERENCES}

Arendt, Hannah (1971 [1978]), The Life of the Mind, New York: Harcourt.

Arendt, Hannah (1954 [1968]), Between Past and Future: Eight Exercises in Political Thought, New York: Penguin.

Bennis, Warren (1989), On Becoming a Leader, Reading, MA: Addison-Wesley.

Bloom, Allan (1968), 'Interpretive Essay' in Plato, The Republic, New York: Basic Books.

Boulding, Kenneth (1961), The Image: Knowledge in Life and Society, Ann Arbor, MI: University of Michigan Press.

Bourdieu, Pierre and Loïc J.D. Wacquant (1992), An Invitation to Reflexive Sociology, Chicago: University of Chicago Press.

Chaleff, Ira (2009), The Courageous Follower: Standing Up To and For Our Leaders, 3rd edn, San Francisco: Berrett-Koehler.

Ciulla, Joanne B. (2004), 'Ethics and Leadership Effectiveness,' in J. Antonakis, Anna T. Cianciolo, and Robert J. Sternberg (eds), The Nature of Leadership, Thousand Oaks, CA: Sage, pp. 302-327.

Eliade, Mircea (1991), Images and Symbols: Studies in Religious Symbolism, Princeton, NJ: Princeton University Press.

Fleischacker, Samuel (2013), What is Enlightenment? London: Routledge.

Foucault, Michel (2001 [2005]), The Hermeneutics of the Subject: Lectures at the Collège de France 1981-1982, vol. 6, New York: Macmillan.

Foucault, Michel (2008), Introduction to Kant's Anthropology, Los Angeles: Semiotext(e).

Gallagher, Shaun (2000), 'Philosophical Conceptions of the Self: Implications for Cognitive Science,' Trends in Cognitive Sciences, 4 January, 14-21.

Gardner, John (1990 [1993]), On Leadership, New York: Free Press.

Gardner, William L., Claudia C. Cogliser, Kelly M. Davis, and Matthew P. Dickens (2011), 'Authentic Leadership: A Review of the Literature and Research Agenda,' The Leadership Quarterly, 22(6), 1120-1145.

Harter, Nathan W. (2016), Foucault on Leadership: The Leader as Subject, New York: Routledge.

Heifetz, Ronald A. (1994), Leadership Without Easy Answers, Cambridge, MA: Harvard University Press.

Hume, David (1739 [1975]), A Treatise of Human Nature, Oxford: Clarendon Press.

Kant, Immanuel (1785 [1997]), Groundwork of the Metaphysics of Morals, Cambridge, UK: Cambridge University Press.

Kant, Immanuel (1790 [1914]), The Critique of Judgment, 2nd edn, New York: Macmillan.

Kant, Immanuel (1797 [1991]), The Metaphysics of Morals, Cambridge, UK: Cambridge University Press.

Kouzes, James M. and Barry Z. Posner (1987), The Leadership Challenge: How to Get Extraordinary Things Done in Organizations, San Francisco: Jossey-Bass.

Laird, Andrew (2001), 'Ringing the Changes on Gyges: Philosophy and the Formation of Fiction in Plato's Republic,' The Journal of Hellenic Studies, 121, 12-29.

London, M. and T.J. Maurer (2004), 'Leadership Development: A Diagnostic Model for Continuous Learning in Dynamic Organizations,' in J. Antonakis, Anna T. Cianciolo, and Robert J. Sternberg (eds), The Nature of Leadership, Thousand Oaks, CA: Sage, pp. 222-245.

Machiavelli, Niccolò (1532 [1991]), The Prince, Cambridge, UK: Cambridge University Press.

Mazlish, Bruce (1990), The Leader, the Led, and the Psyche, Hanover: Wesleyan University Press.

Mead, George H. (1913), 'The Social Self,' The Journal of Philosophy, Psychology and Scientific Methods, 10(14), 374-380.

Nagel, Thomas (1986 [1989]), The View from Nowhere, New York: Oxford University Press.

Nussbaum, Martha Craven (1998), Plato's Republic: The Good Society and the Deformation of Desire, Washington, DC: Library of Congress. 
50 Leadership and the Humanities, Vol. 5 No. 1

Ortega y Gasset, José (1914 [1961]), Meditations on Quixote, Urbana and Chicago: University of Illinois Press.

Patočka, Jan (1995 [1998]), Body, Community, Language, World, Chicago and La Salle: Open Court Publishing.

Plato (1968), The Republic, New York: Basic Books.

Plato (1998), Gorgias, Ithaca, NY: Cornell University Press.

Price, Terry (2006), Understanding Ethical Failures in Leadership, New York: Cambridge University Press.

Rapoport, Anatol (1966 [1999]), Two-Person Game Theory, Ann Arbor, MI: University of Michigan Press.

Rawls, John (1971), A Theory of Justice, Cambridge, MA: Belknap Press.

Roberts, Cynthia (2008), 'Developing Future Leaders: The Role of Reflection in the Classroom,' Journal of Leadership Education, 7(1), 116-130.

Roethlisberger, Fritz Jules, and William John Dickson (1934), Management and the Worker: Technical vs. Social Organization in an Industrial Plant, no 9, Cambridge, MA: Harvard University.

Schellenberg, James (1982), The Science of Conflict, New York: Oxford University Press.

Sells, Benjamin (ed.) (2000), Working with Images: The Theoretical Base of Archetypal Psychology, Woodstock, CT: Spring Publications.

Sen, Amartya (2011), The Idea of Justice, Cambridge, MA: Belknap Press.

Sherman, Stratford (1995), 'How Tomorrow's Best Leaders are Learning their Stuff,' Fortune, 132(11), 90.

Sidgwick, Henry (1907 [1981]), The Methods of Ethics, Indianapolis, IN: Hackett.

Singer, Peter (1979 [1999]), Practical Ethics, 2nd edn, Cambridge, UK: Cambridge University Press.

Smith, Adam (1759 [2010]), The Theory of Moral Sentiments, Mineola, NY: Dover.

Taylor, Alfred Edward (1926 [2001]), Plato: The Man and his Work, Mineola, NY: Courier Corporation.

Voegelin, Eric (1957), Order and History, vol. III, Baton Rouge, LA: Louisiana State University Press.

Von Neumann, John (1928), 'Zur Theorie der Gesellschaftspiele,' Math. Ann. 100, 1928, 295-320. 